\title{
EMBODYING CHARISMATIC AFFECT(IF): THE EXAMPLE OF BRUCE LEE
}

\section{David Hugh Kendall Brown (a)}

(a) Cardiff School of Sport and Health Sciences / Cardiff Metropolitan University. Cardiff, United Kingdom. Email: dbrown[at]cardiffmet.ac.uk.

\begin{abstract}
While the concept of charisma is widely used in the social sciences, its embodied nature is less thoroughly explored and theorised. This paper revisits the key embodied characteristics of Weber's sociology of charisma and re-interprets these using Shilling's $(2005,2013)$ umbrella notions of the body as a source and location of and means for society as a way of analysing the idea of the charismatic body as a force for social change. It then draws on a range of embodied concepts to illuminate how charisma is significant channel of infra and inter-corporeal affective interaction between "leaders" and their followers. In particular, Freund's (2009) social synaesthesia and bio-agency, Massumi's (2002) perspective of affect and the moving body, Thrift's (2010) charismatic celebrity, allure and glamour, Mellor and Shilling's (1997) sensual solidarities, and Seyfert's (2012) conception of affectif. To develop and illustrate this perspective of the charismatically affective body in action, the life of film star and martial artist Bruce Lee (1940-1973) is utilised.
\end{abstract}

\section{Keywords}

Body; Embodiment; Charisma; Affect; Affectif; Intercorpreality; Social Change; Leadership; Bruce Lee; Martial Arts; Celebrity; Bio-Agency; Sensual Solidarities; Allure

This work is licensed under a Creative Commons «Attribution» 4.0 International License. 


\section{ВОПЛОЩАЯ ХАРИЗМАТИЧНУЮ АФФЕКТИВНОСТЬ: ПРИМЕР БРЮСА ЛИ}

\section{Браун Дэвид Хью Кендалл (а)}

(а) Кардиффская школа спорта и наук о здоровье/Университет Кардифф Метрополитан. Кардифф, Великобритания. Email: dbrown[at]cardiffmet.ac.uk

\section{Аннотация}

Хотя концепция харизмы широко используется в социальных науках, ее реализация не так тщательно исследуется и теоретизируется. В данной работе автор пересматривает ключевые особенности понимания харизмы в социологии Вебера и по-новому интерпретирует их, используя идеи Шиллинга $(2005,2013)$, трактующего тело как источник, местоположение и социальный инструмент, чтобы проанализировать идею харизматического тела как движущей силы социальных изменений. Затем автор рассматривает ряд концептов, чтобы обозначить, что харизматичность является важным каналом инфра- и интеркорпореального аффективного взаимодействия между "лидерами" и их последователями. В частности, используются социальная синестезия и биоагентство (bio-agency) Фройнда (2009), а также подходы Массуми (2002) на афффекты и подвижные тела и Фрифта (2010) к трактовке харизматической знаменитости, обаянию и гламуру, чувственная солидарность Меллора и Шиллинга (1997), а также концепция аффектива Сейферта (2012). Для разработки и иллюстрации этой концепции харизматичного аффективного тела в движении используется жизнь кинозвезды и мастера боевых искусств Брюса Ли (1940-1973).

\section{Ключевые слова}

Тело; Воплощение; Харизма; Аффект; Аффектив; Интеркорпореальность; Социальные изменения; Лидерство; Брюс Ли; Боевые искусства; Знаменитости; Биоагентство; Чувственная Солидарность; Обаяние

Это произведение доступно по лицензии Creative Commons «Attribution» («Атрибуция») 4.0 Всемирная 


\section{INTRODUCTION: EMBODYING CHARISMA}

Max Weber evolved the term Charisma from Rudolf Sohm's studies of Christianity (Adair-Toteff, 2014; Joose, 2014) into a sociological concept, in a reformulation sharing similarities with Marx's sociological and secular re-working of Feuerbach's (1854) conception of alienation. Observing societies modernise around the transition from the 19th - 20th Centuries, Weber ([1920] 1965) perceived charismatic forces operating in non-religious areas of social life, most notably in the fields of military and political leadership, as well as its continuing influence in religious institutions. Weber's achievement was to give charisma a significant and enduring sociological interpretation (Adair-Toteff, 2005). His definition, that charismatic ideal-type leaders are, the "holders of specific gifts of body and spirit" and that "these gifts have been believed to be supernatural, not accessible to everybody" (Weber \& Eisenstadt, 1968, p. 19 emphasis added) remains a powerful contribution to our understanding of authority and social change (Turner, 2003). Weber consistently made four specific interpretive observations that were used to underpin his theory of charismatic action and authority, namely that charisma must be performed constantly, recognised by others, is not readily transferred and dies with the body of its bearer. To elucidate:

The charismatic leader gains and maintains authority solely by proving his [sic] strength. If he wants to be a prophet, he must perform miracles; if he wants to be a warlord, he must perform heroic deeds. (Weber \& Eisenstadt, 1968, p. 22)

He [sic] must always be ready to demonstrate his gifts by awe-inspiring acts or risk forfeiting the faith of his disciples. Like the modern sporting hero, his performance is kept under perpetual review by his adulators. (Parkin, 1982, p. 84).

These ideas are also succinctly summarised by Adair-Toteff (2005, p. 198) who confirms, "Weber knew that the leader kept his charismatic appeal only as long as he [sic] was or at least seemed to be successful" and second that, "Weber insists that the charismatic leader is dependent upon his/her followers for recognition" (Adair-Toteff, 2005, p. 195).

While Weber implicates the body in his descriptions of charismatic qualities and actions of leaders, the body is unsurprisingly, given the time of writing, under-developed in his interpretive sociology. More surprising perhaps, is that while a broad range of classic sociological theory, including that from Simmel, Marx, Durkheim and Dewey has been recast in 
light of the "re-emergence of the body" in sociological thinking over the past decades (Shilling, 2013), the concept of charisma has been largely excluded from such re-conceptualising treatments. Notable exceptions to this are Basu and Werbner's (1999) social anthropological study of Sufi Cults as embodied charismatic phenomenon, Freund's (2009) exploration of social synaesthesia as a form of bio-agency embodied in the relationship between charismatic individuals and their followers and Thrift's (2010) discussion on glamour and affect which touches on ideas of charismatic celebrity: these will be returned to later.

Turner (2003, p. 24), citing MacIntyre, reminds that conceptual re-examinations are sometimes frustrated because classical concepts often "live on to perplex us," due to "social changes in which the conditions of application for the original concepts have changed." Undoubtedly, widespread social changes in Western societies including secularisation (Berger, 1967); reflexive modernisation (Beck, Giddens \& Lash 1994), neoliberalism, consumer capitalism and meritocratic individualism (Harvey, 1992) have undoubtedly made attempts to transpose this concept to modern behaviours and contexts more difficult. Nevertheless, many scholars have successfully applied the concept in a variety of fields including; leadership (Shamir, 1995; Beyer, 1999; Beyer \& Browning, 1999; Erez et al, 2008); management (Gardner \& Avolio, 1998); religion (Lewis, 1996; Junker, 2014); new religious movements (Locke, 2004; Joosse, 2012; 2014; 2017); politics (Aberbach, 1996; Tiryakian, 1995; Smith, 2000); martial cultures (Turner, 2003; Brown, Jennings \& Leledaki, 2008; Brown \& Leledaki, 2010; Brown, 2011; Brown \& Jennings, 2011); glamour (Thrift, 2010) and sport (Mullan, 1995; Early, 1996).

Within this literature, discussions of the shift from religious to secular focus of charisma have received considerable attention, as has the status of charisma as a Devine, individual, collective or contextualised phenomenon. This began with Shils (1965, p. 200) who comments that the "unity of the religious and the secular conceptions of charisma" lies in the "attribution of sacredness" -or sacralisation- "to the powers, transcendent or earthly, which men [sic] perceive as ruling their lives" (Shils, 1965, p. 204). More recently, Turner (2003, p. 24) argues that secularisation has meant that "charisma has become mundane, or "everyday", and has lost its special force not because it has become rare but because it has become commonplace." In contrast to Turner, Sennett (1977), in identifying the role of charisma in the context of public life, contends that rather than losing its sacred force, charisma has evolved into a powerful social force. While Sennett agrees with the secularisation of charisma thesis, he argues it has become a relatively "uncivilised," and "narcotic" phenomenon, prop- 
agated by the cult of the personality. Concluding, Sennett (1977, p. 269) suggests that "in a secular society, when 'charisma' is applied to a forceful leader, the origin of his power is more mystifying than in a sacred society". Devine Providence, Sennett (1977, p. 287) posits has been replaced by something far more perplexing because:

To speak of secular charisma as a trivialising force in modern society, in sum, is not to say that the hunger for a charismatic leader is itself a minor or negligible desire. In a perverse way, it is the search for a believable hero, given modern terms of personality.

Sennett's view anticipates Wallis' (1982, p. 26) idea that "charisma is essentially a relationship born out of interaction between a leader and his [sic] followers," and furthermore, that "charisma is not an inherent property of an individual, but of a social relationship, situationally generated...constructed in the process of social interaction" (Wallis, 1982, p. 38). Following Sennett and Wallis, efforts to re-examine the role of charisma in late modern societies have typically focused on the rise and complexification of the bureaucratic institution and how charisma, as a dynamic quality of situated agency and leadership, has evolved to co-exist with modern capitalist, institutionalised bureaucracies (see for example, Howell, 1988; Mullan, 1995; Beyer, 1999; Beyer \& Browning, 1999). Profound developments in public and private life, especially the powerful synoptical effect of mediatising technologies (Sennett, 1977; Mathiesen, 1997; Bauman, 2000) mean that many everyday "banal" practices and beliefs of the few are watched by the many and can quickly become elevated and "sacralised" from the previously profane to the level of the "sacred".

However, in all of these accounts the embodied dimension of charismatic action, as a channel for the inter-corporeal process of sacralisation has tended to remain what Shilling (2013) refers to as an absent presence in that the body is implied rather than focused upon as a subject/locus in its own right.

This interpretation is somewhat redressed by Varga's (2005, p. 231) observation that "in hypermodernity the sacred has shifted from the individual to the body." From this viewpoint, charisma might be interpreted as being a reflexive, fluid and embodied "suture" between the traditionally sacred and secular, with the body being attributed sacredness (Shils, 1965) through what Mellor and Shilling (1997, p. 174) refer to as sensual solidarities emerging "from the immanence of the fleshy body with situations of co-presence and interdependence." Although, as I shall also argue later, presence is not always necessary for the infra-corporeal charismatic affect to occur. 
Mellor and Shilling's (1997) ideas are part of a growing convergence around the importance of materiality of the body in social theory. Freund (2009, p. 28) agrees with Csordas (1997) that the "locus of charisma" means that "for charisma to be seen, it must be in the eyes of the beholder." Within this, as Freund (2009, p. 30) considers, it important to "emphasize material bodies."

In bringing the material body into the concept of charisma as a focal subject, the emotions and affect also come to the foreground. Seyfert (2012, p. 27) suggests that this has always implicitly been the case, commenting, "social theories often turn on a key conception of affect, such as Émile Durkheim's collective sentiment and ritual effervescence, Max Weber's charisma and Georg Simmel's fidelity and gratitude, to name a few." However, Seyfert (2012, p. 29) highlights a key contention within these approaches, that they:

....are still bedevilled by the following conceptual problem: how can an affect be simultaneously defined as an effect that only emerges from the encounter between bodies, and also as a force external to these bodies? In other words, where does affect begin?

This concern with emergence as well as a focus on the co-presence, interdependence and materiality of bodies is consistent with Massumi's (2002) Parables of the Virtual thesis in which he develops Spinoza's neutral monist ideas in outlining an embodied theory of affect and social change. Massumi emphasises that it is not just the material body, but more precisely the moving body that is central to how bodies impact upon one another. He develops this thesis around the important idea of "Body-(movement/sensation) - change" (2002, p. 1) with change being qualitative, infracorporeal and emergent through the body's movement (not all of which are directly visible as for example thought expressed as thinking-feeling is included here). Massumi's pre-social (but significantly not asocial) stance on the body's capacity to affect and be affected is possible because he situates affect in a "zone of indeterminacy" which he also describes as the "field of emergence." In other words, while affect occurs in bodies it neither belongs wholly to the individual nor to exterior fields or individuals. In application, we might consider that the particular movements of charismatic bodies, captivates and affects bodies into feeling and moving in ways different than that which they otherwise might - stimulating qualitative inter and infra corporeal social change.

Seyfert's (2012, p. 27) approach is largely consistent with Massumi's starting point when he develops the notion of affect in a sociological direction and transposes Foucault's notion of dispositif in suggesting affectif. 
Like Massumi, Seyfert also draws on "a Spinozist understanding of the body to conceptualize the receptivity and mutual constitution of bodies" and significantly:

how affects do not 'belong' to anybody; they are not solely attributable either to the human or to any kind of body alone, but emerge in situations of the encounter and interaction (between bodies) (Seyfert, 2012, p. 27).

An affectif, he suggests, "consists of all relevant social bodies and their differentiated interactions (haptic, olfactory, aesthetic, psychic, semiotic, neurological, electrical, intensive, etc.)" (Seyfert, 2012, p. 42). Embodying charisma then involves identifying and situating a charismatic's embodied actions within an affectif. Finally, this paper also draws on Thrift's (2002) ideas around charismatic celebrity in which he integrates notions of celebrity, glamour, allure, style with affect, these will be addressed later.

In this paper, the analysis is organised by Shilling's (2005) proposition that contemporary sociology might usefully take a multi-dimensional view of the (charismatic) body as source of, location for and means of society. Shilling argues that the tripartite foci of source, location and means are not only multidimensional but also constitutional in that each represents analytically irreducible elements for understanding the evolving relationships between body and society as informed by a range of social theory. Shilling (2005, p. 20) cautions that these elements "should not be considered mutually exclusive options or totally separate functions of the body, but constitute instead co-existing moments in, or dimensions of, an ongoing process that manifests itself over time." Importantly, he also clarifies that "the balance between these ongoing aspects of its existence as source, location and means undoubtedly shifts over time depending on a number of variables". As such, these insights provide a framework for bringing together a more focused reformulation of the role of the charismatic body in any given context, event and, following Wallis (1982), process of interaction.

In what follows, details of each of Weber's observations of charismatic action, outlined in the introduction are set alongside Shilling's (2005) notions of the (charismatic) body as source, location and means for effecting and affecting society. In order to illustrate these ideas, the charismatic actions of Bruce Lee (1940-1973) are considered. Lee has been selected because his embodied charisma is subject to a litany of public documentation, which following Smith (2000), suggests Lee's influence represented a form of secular salvation aligning with Weber's idea that charismatic leadership is encapsulated in a transformative salvational dis- 
course, nicely summarised by Parkin (1982, p. 77) as "obey me because I can transform your life." This is clearly evidenced by a 2009 TV documentary film directed by Steve Webb (2009) entitled How Bruce Lee changed the world. The film, with testimony from a diverse range of his followers and admirers, documents how Lee's charismatic action affected them personally and also led to global cultural change involving the opening, proliferation and transcultural development of the martial arts, the evolution of Mixed Martial Arts (MMA), contemporary popular philosophy combining secular spiritual forms of self-help, body conditioning in the fitness industry, the realist action movie genre, and the challenging of ethnic relations in ways which empowered ethnic minority groups. As Thomas (1996, p. x) recounts, Lee "possessed a natural charisma that made him stand out from a crowd of even hundreds." Thomas also noted that "Bruce Lee inspired people" (xvii) a point which resonates with Parkin's (1982) interpretation of Weber's ideal typical mode of follower compliance expressed as inspirational, a view complimented by Junker's (2014) idea of charisma both generating and being sustained by follower agency. As such, Lee's actions typify how embodied charisma "is a driving creative force which surges through the established rules whether traditional or legal, which govern an existing order." (Giddens, 1971, p. 161).

In conclusion, the paper briefly reflects on these ideas beyond the example of Bruce Lee to consider how the idea of embodied charismatic affect is a significant channel of sacralised inter/infra-corporeal interaction between leaders of sociocultural movements and their followers, thereby aiding our identification of an embodied charismatic affect(if) in the dynamics of embodied action, social power and change.

\section{LEE'S BODY AS A SOURCE FOR CHARISMATICALLY AFFECTIVE PERFORMANCES AND RECOGNITION}

The combination of Bruce Lee's body size, condition and ethnicity served as a significant source for his embodied charismatic affect. As a child, adolescent and adult, Lee was relatively small in physical stature (as an adult he was five feet seven and a half and around 135 pounds). In a statement that echoes, Smith's (2000) commentary on the unremarkable early lives and status of political leaders Churchill, Hitler and LutherKing, biographer Little (1998, p. 12) affirms that "growing up in Hong Kong, Bruce was not an especially gifted youngster. In fact, his mother recounted to me that Bruce was a skinny little kid." Nevertheless, it is well documented by Little (1998) and other biographers (See for example, Thomas, 1996; Polly, 2018) that Lee had a lot of street fights throughout 


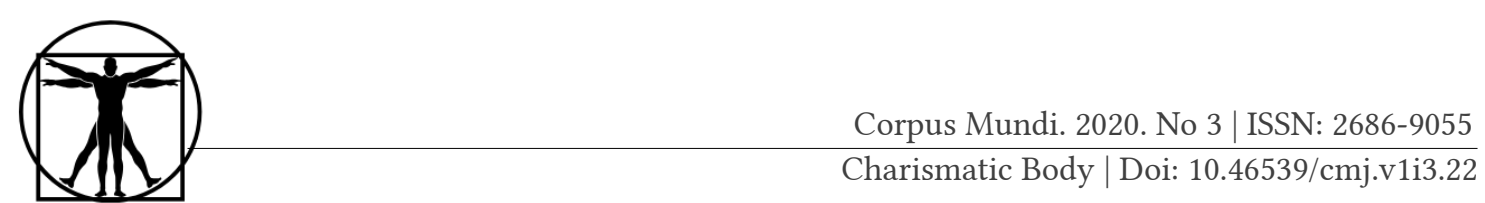

his childhood and youth as a result of being involved in youth street gangs in Hong Kong. Subsequently, Lee developed what has elsewhere been referred to as an efficiency-efficacy disposition towards combat in martial arts (Brown \& Jennings, 2013) which was to re-emerge as a key orientation in his martial arts performances later in his career.

This situation must be set in context with the prevailing culture of Asian martial arts at the time; Martial skill was considered sovereign over pure strength and power and the ability to demonstrate efficacy against larger, stronger, faster and even younger opponents was an essential social performance to be displayed (and managed via a range of credible physical performances). Demonstrable skill lent credence to the idea that the art in question was technically, a superior self-defence/fighting system. Traditionally, a master's martial skill tended to be exhibited in closed situations and relatively rarely put to the test in live combat against dangerous opponents, as failure would undermine the perceived efficacy of the system. Subsequently, martial arts systems, or styles, were shrouded in secrecy and fiercely protected and promoted through tradition and unyielding fidelity of the student to the system and master. In contrast, Lee's body came to be viewed as a charismatic source in that he was stimulated by and (later) able to demonstrate the need for efficiency and efficacy in the face of real, uncooperative and often larger opponents in real world combat situations.

A particular incident illustrates this idea of Lee's body as source of charismatic performance: a story that serves a mythopoeic function amongst his followers to this day. In 1965, the experience of a successful but physically draining challenge match with Wong Jack Man, an allegedly lesser skilled opponent ${ }^{1}$ led him to realise the significance of his (lack of) physical conditioning. He subsequently and emphatically brought physical conditioning into the mainstream of his own training and subsequently martial arts training by using his own body as an exemplar location for the radical changes to the martial body that could be inaugurated by extreme, functional, physical conditioning regimen. This will be returned to later.

The second element where Lee's body served as a source for his emerging charismatic performances was his experience of having a mixed "race" ethnicity: Lee's father was Chinese, and his mother Grace Ho was partly from "Eurasian" descent ${ }^{2}$. The ethno-racial hierarchies prevailing in Hong Kong and the United States during the 1950s, and 1960s, meant that

1 Rossen (2015) presents a balanced researched account of this much discussed incident. Polly's (2018) account is detailed and includes a number of testimonials.

2 According to Polly (2018) one half English, one quarter Dutch-Jewish and one quarter Han Chinese. 
despite being from a relatively affluent family, Lee consistently found himself in the position of Other and subjected to abusive verbal, physical and symbolic discrimination on these grounds. Lee's experience of racism in 1950s Hong Kong impacted upon his life in numerous ways, from being involved in fights in street gangs both with and against "white" colonial children (which ironically, he was also sometimes identified as), to being pressured to leave his Wing Chun Kung Fu training with Master Yip Man ${ }^{1}$ due to other Chinese students finding out about and objecting to his part European ancestry (Thomas, 1996) ${ }^{2}$. While, Lee continued to train with Yip Man, this issue returned later with Yip Man's own reluctance to share his art with "foreigners" meaning he eventually stopped teaching Bruce Lee the art of Wing Chun altogether (due to Lee wanting to teach Kung $\mathrm{Fu}$ to non-Chinese students while living in America). Later, Lee's experiences in America were equally problematic as he realised upon his arrival that he had joined an ethnic minority in a 1960s America; Chinese ethnicity was physically, socially and culturally stigmatised as sub-altern Other (Gramsci, 1971).

These experiences of racism and ethnicism bolstered Lee to demonstrate (materially and symbolically), through his real world actions (in the form of demonstrations, tutelage of westerners and real combative use of martial arts) and his cinematic depictions (through scripting, directing and acting in the four martial art films he is most widely known for), that the Chinese as the "sick man of Asia" (see Scott, 2008) stereotype was a racist, ethnicist myth and, further, that marginalised peoples everywhere could and should challenge their subordination in whatever ways were available to them. Additionally, and paradoxically Lee came to recognise that his mixed Asian-European ethnic heritage, while being a source for an Othered subaltern bio-social position, also provided him with a unique bio-agentic opportunity, to demonstrate that the Asian martial arts (along with non-Asian martial/combat arts) are a resource that should be freely available to all people and not, as was the case in 1950s and 1960 s America and Hong Kong, ethnically "owned" and segregated skill sets. Indicative of this stance, in a 1971 Pierre Berton Show interview, when asked whether he considered himself as Chinese or American, Lee responded thoughtfully, "I think of myself as a human being."

Shils (1965, p. 200-201) points out that the secular and sacred aspects of charisma operate not as a dichotomy but rather on a continuum in which the unifying aspect is what he refers to as awe-arousing centrality,

\footnotetext{
Ip or Yip Man (1893-1972) was a Master of the Wing Chun Kung Fu style

There are conflicting accounts of the nationality of Lee's mother. While it is agreed she was Caucasian, according to Russo (2016) there is a discrepancy of factual information between her declaring her nationality as part German (in Hong Kong) and part English (in the USA).
} 


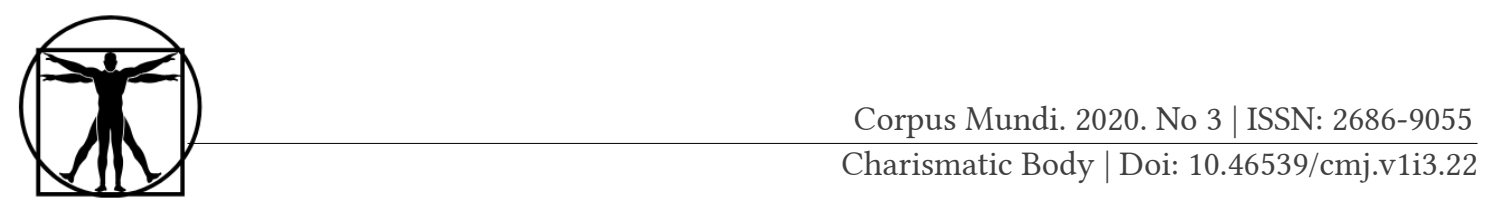

which is "some very central feature of man's [sic] existence and the cosmos in which he lives. The centrality coupled with intensity, makes it extraordinary." Lee's body can be said to be a source of his charisma because of the awe-arousing way Lee's body's initial limitations served to stimulate his subsequent actions. By overcoming these limitations, Lee's bodily performances and achievements were magnified and intensified into something that took on charismatic qualities in the eyes of his followers and admirers, inspiring them not just to follow him but also to act differently in their own lives.

Freund's (2009, p. 26) notion of bioagency is helpful here as it helps "call attention to melded quality of mindbody relationships," Lee's charismatic emergence corresponds with what Freund (2009, p. 30) calls:

\begin{abstract}
A form of social synaesthesia where the word is made flesh and charisma is materialized. Again, these are 'extraordinary' experiences, but, following Merleau-Ponty (1962), they point to the everyday tendency for us to color, sharpen, change the tone and texture of experience, and refocus our psycho-sensorium - the embodied subjectivity through which we exist in the world.
\end{abstract}

Lee's unrelenting self-transformation affected others. The re-focusing of his own psycho-sensorium, by changing his initially small and ethnically marginalised body resembled what Thrift (2010, p. 303) refers to charismatic celebrity "of the kind found among major stars of stage and screen, certain (and by no means all) politicians, some sports stars," and "some top models," as a social construction of the magical persona. It is also useful here to consider Thrift's discussion of glamour, as "a kind of secular magic conjured up by the commercial sphere" (p. 297) which has four of identifiable features, each of which are relevant to Lee's case. First, public intimacy (the illusion of availability); second, synthetic (rather than direct) experience; third, "a special allure made up of physical attraction, lack of self-consciousness, and a perceived indifference" (p. 304) and finally, an "unresolved intensity" which comes into being through the possession of contradictory qualities (such as strength and vulnerability, innocence and experience etc). Lee's bio-agentic body-as-source contained just such intimacy with his followers, physical attraction (people could identify with his marginal status and overcoming and he taught his martial arts to students), synthetic experience (most people "saw" Lee perform from a distance and/or in mediated form - most never "felt" his performances, yet they seem to still "feel" his intensity) lack of self -consciousness about his ethnic status (in the sense he refused to be bound by a category), unresolved intensity (he advocated living to the full and striving for 
perfection and achievement of self which was made all the more evident from his body being the source of his "physically limited" and ethnically marginalised starting point) and he also demonstrated indifference towards any aspect of tradition which stood in his way. Each element combined to form a powerful allure. Importantly, the charismatic celebrity personality, Thrift (2010, p. 305) argues:

is neither person nor thing but something in between, an unobtainable reality, an imaginary friend, and an accessory, a mental image that can be conjured up in the imagination, explored, and made one's own, something that is at issue in the world.

The notion of allure aligns with Massumi's idea of "zone of emergence" and is clearly stimulated by Lee's body as a source of charismatic affect. Lee shared his project of self with others, stimulating what Blackman (2012) refers to as "affective interpellation." It reached out (it still does) and stirred others who were in "differently similar," often marginal, positions, into action, to strive, to act and to improve themselves and their situation. Indeed, Lee himself iterated this in one of his many poignant quotes that are used today in many self-improvement fora:

If you always put limits on everything you do, physical or anything else, it will spread into your work and into your life. There are no limits. There are only plateaus, and you must not stay there, you must go beyond them.

I am not teaching you anything. I just help you to explore yourself.

This overcoming and transformation of his own body's physical and social limitations was, therefore, the embodied source underpinning his charismatic personality and "allure" and enabling a kind of "affective contagion" (Thrift, 2008).

\section{THE BODY AS A LOCATION FOR CHARISMATIC PERFORMANCES AND RECOGNITION: AN EMERGING EMBODIED CHARISMATIC AFFECTIF}

As has been argued above, while the materiality of Lee's physical body performing martial arts is a significant source of his charisma, it only becomes affective in symbiotic relation to what his body was and has become in the social environment in which this occurred. Following Seyfert (2012), Lee's embodied charismatic affect, in an interpersonal in situ sense, becomes affectif in a distributed and distanciated sense. There are four elements of Seyfert's (2012, p. 33-34) notion of affectif. First "affects arise 
from an affectif the way power arises from a dispositif," in that "Both emerge from an assemblage of heterogeneous elements instead of being 'located at - or emanating from - a given point' (1980, p. 198) for example from a subject or a human body." Secondly, this not only involves accounting for all the elements involved but also focusing on how the connections between these elements constitute "affective interactions out of which affects (and effects) emerge" (Ibid). Third, "an affectif also stands for a historical formation in so far as the affective interactions that describe the relations of its elements are not always the same" (Ibid). Finally, he side sidesteps any universalising tendency for affectif, positing that:

Some bodies are more affectable than others...Obviously, the cultural and historical variations of individual affectabilities and affective interactions are correlative to each other, simply because each interaction requires particular receptive and interactive capabilities of a body and vice versa. (Seyfert, 2012, p. 33-34)

Seen from this perspective, Lee's charismatic body and the affectif that emerged from his movements made him what Thrift (2010) refers to as a fractal person, in that "the person lies in between as a dividual rather than an individual" (p. 303). Lee was becoming just such a fractal persona - primarily through the extraordinary "cultural body work" (Shilling, 2005) to transform his body and make it a location for charismatic affect which was a unique and awe arousing cultural nexus for elements of martial cultural practice (at the time). Lee's body (along with significant other pioneering martial artists including Jigoro Kano, Morihei Ueshiba and Ed Parker) have been credited with being the location for a particularly innovative blend, interpretation and performance of techniques together in a coherent and distinctive form that traditionally was referred to as a style or system (Brown, 2011). This is important, because as Thrift (2010, p. 297) terms it style, or "style of allure":

is a modification of being that produces captivation, in part through our own explorations of it...Style, in other words, can be counted as an agent in its own right in that it defines what is at issue in the world that we can engage with.

Provocatively, Lee rejected the terminology of style to refer to his martial art, preferring the iconic term, the "style of no style" or "the formless form" (Lee, 1975, p. 23) a logic undoubtedly inspired by Lee's Taoist philosophical orientation, Lee's life experience of being excluded from traditional martial arts communities, his personal view of the practical weaknesses of many traditional martial arts, and his seeming general dislike for 
categorisation. All of these aspects clearly affectively interpellated others with similar experiences, who were receptive to practical alternatives to traditional martial arts.

Lee's "style of no style" was also alluring and contagious, precisely because the idea tapped into the Zeitgeist of the 1960s America (more on this later) and it was awe-arousing precisely because he developed and demonstrated this "formless form" materially with and through his own body. By the mid 1960s, Bruce Lee's body was becoming a celebrated charismatic location (or as Massumi might put it, a zone of emergence) for a new transcultural martial art (Jeet Kune Do). Additionally, Lee was developing and displaying one of the most skilled and aesthetically impressive martial physiques hitherto ever seen, and highly impressive even by today's standards. Lee's widow, Linda Lee Cadwell and fellow actor, martial artist and friend Chuck Norris (cited in Little, 1998, p. 18 \& 172 respectively) illustrate the significance of this transformation:

I know that millions of his fans are convinced that Bruce was born with a special body; they have watched him exercise his extraordinary strength, seen his agility, studied him as he flexed his small but marvellously muscled frame. Many of them simply do not believe it when I explain that Bruce built up his outstanding physique through sheer application and willpower; through intense training. (Lee Cadwell)

No other human being had ever trained the way that Bruce trained - fanatically. He lived and breathed it from the time he got up at six o' clock in the morning until he went to bed at night. He was either working out or thinking about it. His mind was always active, never resting. He was thinking about what he could do to improve himself or what new inventions were possible. (Norris)

As the quotes illustrate, Lee's "fanatically" dedicated actions embedded such high levels of condition, skill and understanding in his performing body that he appeared to have near supra-natural abilities (relative the socio-temporal context he inhabited). As Thomas (1996, p. 286) reflects on Lee's awe-arousing charismatic allure:

Bruce Lee was unique as a screen fighter because he was real...to see Bruce Lee on film is to see a human body brought to a level of supreme ability through a combination of almost supernatural talent and a lifetime of hard work...Like seeing a brilliant goal by Pelé or hearing a blistering guitar solo by Jimi Hendrix, the human imagination doesn't need to be "captured" when what it witnesses is real. 
Furthermore, Lee made his body a unique bio-physical location for a combination of martial arts spanning both Eastern and Western martial cultures. These included an eclectic blend of techniques from the arts of Wing Chun Kung Fu, Tai Chi, Judo, Western fencing, boxing and wrestling techniques. Such trans-art and trans-cultural blending and eclecticism was virtually unheard of at this time (with the possible exception of Ed Parker's American Kenpo Karate) when many traditional arts typically dictated a strict allegiance to learning a discrete and complete system in virtual isolation from other systems. Lee's body had quite literally become "a location" for the transcultural amalgamation of martial practices which, through his performances, presented a radical challenge to the authority of many traditional martial cultures. Taken together, Lee's martial art, his body and his philosophy for life which accompanied it, became a zone of emergence, affectively alluring, contagious, interpellating and when taken in the broader context, it is possible to begin to consider these as elements of Bruce Lee's charismatic affectif. Moreover, the performative aspect of Weber's theory of charisma, alongside notions of affectif are more evidently brought into focus by Shilling's notion of body as means which are addressed next.

\section{LEE'S PERFORMING BODY AS A MEANS FOR CHARISMATICALLY AFFECTIVE PERFORMANCES AND RECOGNITION}

Lee's martial arts performances in teaching, demonstrations and films are how most people "know" Lee and indeed how they are affected in inspirational ways by him. In Seyfert's (2012) terms, Lee's charismatic affectif has to be seen as a heterogeneous range of contributing elements that come together and out of which intra and infra corporeal affects emerge through others and also back onto himself. The period of activity between 1970 and 1973 for Lee was intense as he tapped into the Zeitgeist of the period becoming an agent of change in both Western and Asian cultures. He simultaneously embodied and promoted American individualism, martial pragmatism, secular spirituality combined with East Asian philosophy, ethnic pluralism and subaltern resistance. Each of these elements contributed to Lee's embodied charismatic allure as he created a space at the vanguard of changing cultures. However, there is one element which is, following Weber, a necessary recurring and central aspect to the emergence of Lee's charisma - his moving performing body. Lee's performances, for his time, had a superlative and radical quality in movement and these movements literally moved other people, encouraging 
them to feel like they wanted move and to change their own bodies and life trajectories ${ }^{1}$. In a dual sense then this echoes Massumi's (2002, p. 1) core idea of "Body-(movement/sensation) = change." Dual because, Lee himself appeared highly intuitive to learning from his body and constructed Jeet Kune Do largely around this principle, and also because he inspired his followers to do the same through being energised by his movements, so in essence to follow his way as a means to finding their own way. The underlying importance of the body in movement as a means for this charismatic affect is clarified by Thrift (2000, p. 45) who contends that body practices:

allow the present to be intensified since they produce both an intensified sense of body movement and, at the same time, focus and enhance that movement. They are tempos of involvement without any necessary intention or initiative. They ('flow' time through the minute particulars of body movements that both have effects and yield experiences. They are 'performed dreams' (Schechner, 1995), 'virtual actualizations' of time which allow consciousness to become acute without necessarily being directed by drawing on the non-cognitive.

Lee used his moving performing body as a means through which his charismatic affect emerges and in his films in particular he "performed dreams," cinematic and actual performances that overcame physical, ethnic and traditional boundaries that encouraged his followers to also dream of overcoming. This is consistent with, but an extension of, Gardener and Avolio's (1987, p. 43) exploration of a dramaturgical view of charisma and in particular, the idea of impression management and staging in order to build a charismatic relationship:

Charismatic leaders appear to be very aware of the importance of nonverbal behaviors to their image. Thus, they use their superior acting abilities to orchestrate nonverbal and expressive behaviors that followers see as highly fluid, outwardly directed, and animated (Bass, 1985, 1988; Weierter, 1997). Whereas many such behaviors involve spontaneous displays of genuine emotion, others are scripted in advance or through improvisation to maximize their impact. Their inspirational effects are readily apparent from audience reactions. For instance, people describe the voices of charismatics as captivating and their eyes as magnetic and hypnotic (Bryman, 1992; Willner, 1984). Charismatics also project a powerful, confident, and dynamic presence through their body posture, speaking rate, gestures, smiles, eye contact, and touch.

1 There is a powerful and literal illustration of this in a Webb's (2009) documentary which depicts scenes following the cinematic release of Enter the Dragon of Western audiences (mainly young men) coming out of cinema's and spontaneously launching into simulated Kung Fu fights. 


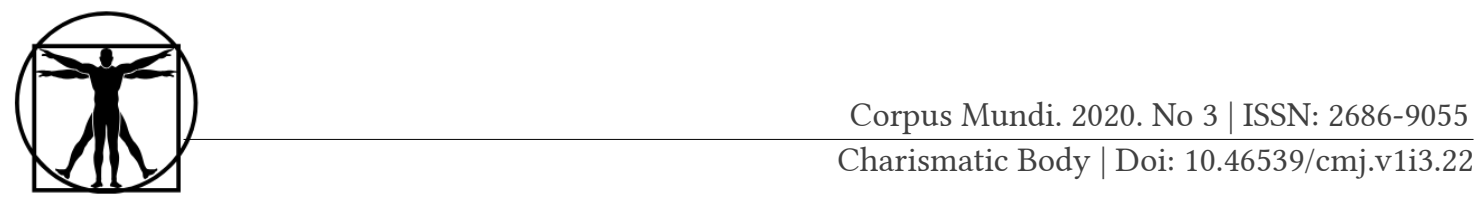

In martial art cultures there is an expectation that exhibitions of technical skill mastery be very accomplished. If the martial artist is or was also an accomplished fighter this also seems to further add to the physical aura created, but the two qualities should not be conflated. While combat sports and self defence systems focus on the outcome of technique (driven by the win/loose binary that defines modern sport (Storm, 2010)) and real life confrontations, the practical demonstration of technique itself continues to hold sovereign importance in many traditional martial art cultures. This forum of the exhibition hands a degree of control to the charismatic leader, which Gardener and Avolio, (1987) refer to as staging. The martial artist has a mandate to impress (and to an extent, entertain) the audience who is, in Weber's terms demanding it through the need for bioagentic "proof". Moreover, performances are demanded by would be followers evinced through subcultural narratives such as: "does this technique/art actually work? Are you any good? If you cannot do it - how will you show me how to do it?" And the important cultivation/salvation narrative of, "what kind of a person can I become if I follow you and your art?" Such narratives connect with House and Baetz's (1979, cited in Gardener \& Avolio, 1987, p. 29) idea of the charismatic relationship, through which charismatic leaders "by the force of their personal abilities are capable of having profound and extraordinary effects [and affects] on followers." It should be noted that Lee was an experienced actor in his childhood having appeared in around twenty films by the age of 18 and was comfortable with such performances both on and off screen. Lee emphatically used his body as a means to stage charismatic action in a way which echoes Gardener and Avolio (1987, p. 41):

Regardless of their origin, esteem and power are critical for charismatic leaders, who must appear to possess some special expertise or skill, as well as a capacity to use it to achieve influence, in order to convince followers that they can attain their lofty goals and thereby secure their trust and commitment.

Lee used his moving body's physical and martial prowess deliberately as means to create a zone of emergence, to produce interpellation and affective contagion. A number of these demonstrations were recorded on film which has served to "sacralise" further, the significance of these actions for future generations as well. Perhaps Bruce Lee's most decisive watershed public demonstration as a martial artist was at the 1964 (and again in 1967) Long Beach International Karate Championships hosted by the late Ed Parker. Parker, himself a celebrated innovative creator of American Kenpo Karate, invited Lee because he had already "recognised 
something in Lee." Parker's invite allowed (read "demanded") Lee to demonstrate (read "prove") his skills publicly. This he did emphatically, stunning the crowd with hitherto unseen Chinese Kung Fu techniques, localised power such as the "one inch punch" and demonstrations of Wing Chun's Chi Sau sensitivity drills. Linda Lee-Cadwell (1989, p. 70) describes the event that unfolded:

\begin{abstract}
Bruce's demonstration was viewed by a large audience which included many leading black belts and instructors. Most people in attendance agreed that Bruce not only had something different to offer, but possessed a unique personality in his own right. As one observer commented, 'He had something the others didn't have - you could see it in the way he explained his art, in the way he talked'. He was utterly dynamic that night and one couldn't help being drawn to him, even those who knew very little about the arts found themselves listening to him intently. Luckily, Ed Parker filmed Bruce's demonstration, which was to prove a big break.
\end{abstract}

Indeed, the film footage becomes a key part of how Lee's embodied charismatic affect becomes an affectif stretching out across space and time. It remains available on sites like You Tube ${ }^{1}$ along with the myriad of Lee's other filmed training and demonstrations (usually repeated). Although low definition and largely un-produced, these have become celebrated "sacralised" evidence of "real" martial arts for Bruce Lee's followers. It is not difficult to see why his on-screen and public charismatic affect interpellated legions of Westerners into being Kung Fu film followers and practitioners (and continues to) if we account for the limited exposure Westerners had to such martial culture had hitherto had at this time - it was awe inspiring. Contra to Sennett's (1977, p. 276) view that in political and celebrity fields "secular charisma," in its televised, mediated and synoptic form, deflected "the masses of people from investigating much feeling in the social issues at all," we might also view these media as having the potential for mediating social synaesthesia. A synaesthesia of the charismatically affective allure emerging from the movements of an awe-arousing body which gave rise to "Dionysian experience that can create a condition of crisis all of its own." In Lee's case, it demonstrably affected people, even at a distance, into acknowledging there was problem (crisis) and a solution in the martial arts (that traditional martial arts didn't always work, and his solution: that to work they must be eclectic, practical and constantly revised by individuals according their own bodily and situational needs). This was something which challenged the tradi-

1 For example 'Top 10 Bruce Lee Moments' has over 93 million views at the time of writing. 


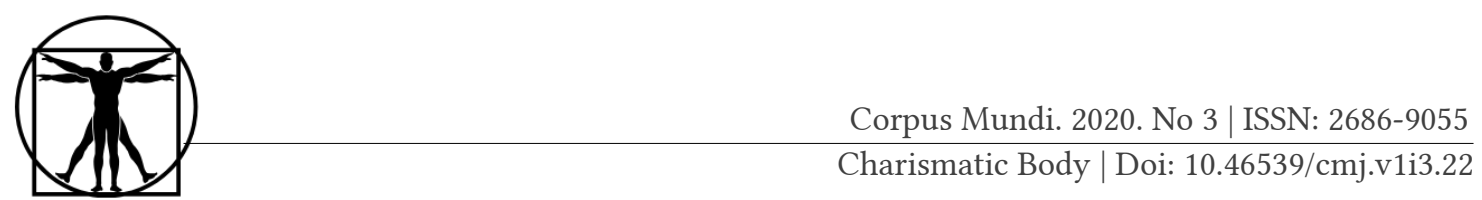

tional martial arts establishment, but also connected with the Zeitgeist of an emerging global martial culture as well as counterculture at this time.

Moreover, Lee used his own moving body as the vehicle for demonstrating that his own martial art was the proof of this solution. Therefore, Lee's use of his body as a means inspires by example, an affective bioagency, which unlike many martial arts action film actors, was underpinned by his "real" (physically "real" athletic cinematic and otherwise recorded performances) embodied martial charisma which he consistently demonstrated (body as means) with students during training, challenge matches, public demonstrations and interviews. This is well illustrated by actor, Jeet Kune Do student and long-term friend James Coburn (cited in Little, 1998, p. 150):

Bruce brought over this big, heavy tackle bag...football players use them a lot. We hung it up with a big L-iron out there and used it for practicing our side kicks...Anyway he was saying, "Okay now, this is the way to do it," and he kicked this bag, which must have weighed between 100 and 150 pounds. Well he actually kicked a hole in the middle of it! He broke the chain that was supporting it, and it went flying out into the lawn. I remember that it was filled with rags and there were rags everywhere...It was really an astounding thing to see.

Another former student and Jeet Kune Do teacher, Tacky Kimura (Seven, 1998) reported:

The real Lee, Kimura says, was greater than the myth. He could stand five feet from you, warn you it was coming and then touch your face before you could do more than flinch. He didn't need camera tricks. His martial art was grounded in a resilient philosophy. That's why he hasn't been replaced.

A third, powerful illustration of Lee's use of his body produce charismatic affect is provided by Tom Tannebaum, who describes his first encounter with Lee. Tannenbaum who had already trained in Karate and was then the head of Paramount TV and in charge of developing the TV series Longstreet (in which Bruce was suggested might play a role), entered Lee's martial arts studio with a view to finding out about whether Bruce Lee was the "genuine article" for potential casting and also, was deciding at a personal level whether to begin training as a student of Lee:

He came over to me and said, "I'm going to hold this catcher's mitt and you hit it." Now, I weighed about 200lbs and Bruce at that time weighed about 132. I hit it, and I hit it hard. Bruce said, "Now you hold it," Without even pulling his striking hand back, and using just the torque of his body, he lit- 
erally knocked me across the room. In fact, I hit the wall so hard that a picture fell down. It was embarrassing because all the students in the class looked at me. Still, I was fascinated because I had never met a man who weighed almost seventy pounds less than me who could knock me across the room. Bruce said, "That's the power. Now I'll show you the speed." He put a nickel in my palm and said, "close your fingers before I grab it out of your hand." He moved like lightening and I quickly clenched my fingers. When I opened my hand, the nickel was gone and in its place was a dime. That's all I had to see. I said, "That's fine, I'm yours." So I started taking lessons from Bruce. (Tom Tannenbaum, cited in Thomas, 1996, p. 129).

Tannenbaum's testimony illustrates Bruce Lee's embodied charismatic affect and affectif because without the mediated affect, Lee was causing in martial culture, Tannenbaum would not have attended the session in the first place. Once there, it shows how embodied charismatic affect through the performing martial body was required by potential followers for them to believe in their leader ("That's fine, I'm yours"). It also shows how Lee was, in an embodied sense able, willing and prepared to provide these performances to audiences and thus used his martial performances as a means to display charismatic authority as a master martial artist.

What separates Lee's embodied charismatic affect from other martial artists was that his performances were not just effective/affective but also carried a message that was poignant for the time. Outside of practicing martial arts communities, Lee is mostly, celebrated for his four martial arts films and the philosophies of life they contained. As previously mentioned, he was an experienced childhood actor and he made great "use of articulation and impression management practices to inspire followers in pursuit of the vision" (Gardener \& Avolio, 1987, p. 29). In an interview on the Pierre Berton show (1971) he famously drew on these skills to deliver his vision for martial arts and for how to approach living life by repeating the character lines he co-wrote with Stirling Silliphant, the executive producer of the TV show Longstreet:

Don't get set into one form, adapt it and build your own, and let it grow, be like water. Empty your mind, be formless, shapeless - like water. Now you put water in a cup, it becomes the cup; You put water into a bottle it becomes the bottle; You put it in a teapot it becomes the teapot. Now water can flow or it can crash. Become like water my friend.

These lines, in tandem with, his performance of them on screen, both in the series and a subsequent interview were evidently adapted from elements of Lao Tze's Taoist Tao Te Ching ([1891] 2006, p. 49) which makes 


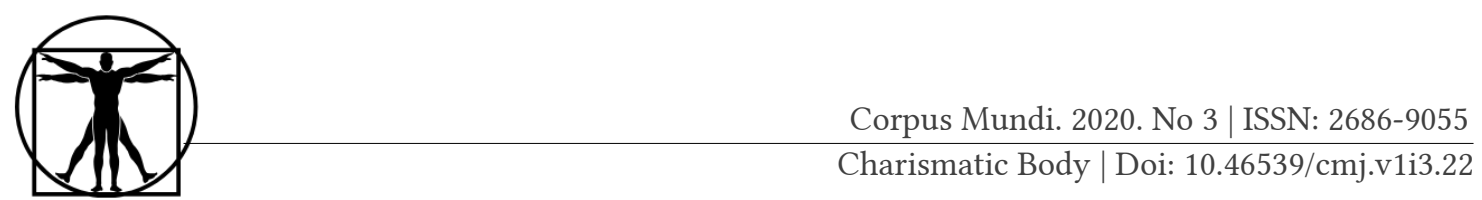

consistent use of the metaphor of water and in particular verse 78 which states:

There is nothing in the world more soft and weak than water, and yet for attacking things that are firm and strong there is nothing that can take precedence of it;- for there is nothing (so effectual) for which it can be changed.

This and many other maxims Lee developed, have significantly contributed to Lee being "canonised" by his many followers as not only a great actor and martial artist but also being described as a philosopher, spiritual guru and even a minor prophet for marginalised peoples in secular times ${ }^{1}$.

Lee's embodied charismatic affect(if) here aligns with Smith (2000, p. 105) who contends that it is important to retain the idea that, "charisma is linked to the quest for salvation and issues of purity, sacrality, profanity and pollution," and that "the nascent cultural dimensions of Weber's original argument are maintained and given content." There are evident parallels here with narratives of other charismatic leaders identified in Smith's (2000) analysis. including Winston Churchill and Martin Luther King, who were also not initially seen as special or charismatic figures in their social fields - but became so viewed due to the way in which they charismatically affected the situations in which they found themselves, tapped into the Zeitgeist of the moment and provided seemingly empowering solutions for the populations who were contextually pre-disposed to listen to them. Moreover, Smith (2000, p. 109) argues "there are many local ways of pursuing the universal quest for salvation....it is likely that they will draw up local religious traditions in other cultural settings". However, as Smith (2000, p. 110) also affirms "fundamental to this process are the negative symbolisms against which heroes and salvation narratives are constructed."

Lee's message offers an example of both these elements of charisma. Lee's negative symbolism was what he proposed a salvation from; the chains of traditionalism; docility of self in modern life; racism, ethnicism and creative stagnation. Importantly, while these were often directed at the martial arts specifically, he also did this in a way that commented on life in general - something that cemented his wider appeal. In response, Lee's salvation narrative was cultivational, containing individualistic, material (as opposed to transcendental) elements of secular spirituality with East Asian philosophy, each of these elements were remarkably in tune with cultural shifts and blending beginning to emerge in Western and

1 These various views are expressed in the 2009 documentary "How Bruce Lee Changed the World." 
Eastern cultures during the late 1960s and early 1970s. As such Lee's charismatic affect became an affectif - affectively distributed- in ways which contributed significantly to what Campbell (2007) describes as a process of cultural Easternization of the West taking place at the time.

By way of illustration, Lee's negative and positive symbolisms are present in many lines Lee inserted into his films and books. For example, in Enter the Dragon (1973) when teaching a young student, Lee comments on his martial movements:

What was that? An Exhibition? We need emotional content. Now try again!

Don't think, feeeeel...it is like a finger pointing away to the moon. Don't concentrate on the finger or you will miss all that heavenly glory! $!^{1}$

Art is the way to the absolute and to the essence of human life. The aim of art is not the one-sided promotion of spirit, soul and senses, but the opening of all human capacities - thought, feeling, will - to the life rhythm of the world of nature. So will the voiceless voice be heard and the self be brought into harmony with it. (Lee 1975, p. 10) ${ }^{2}$

However, perhaps the celebrated "Colosseum scene" in Way of the Dragon (1972) is the superlative illustration of the combination of Lee's embodied charismatic affect, dramaturgical skills and philosophy combined in a cinematographic moment. This was the first film that Lee wrote, directed, produced and acted and as such the messages it contains are Lee's own. As film critic Breihan (2015) puts it:

Half an hour of the movie goes by before the first fight, and Lee pulls it off anyway, thanks to his burning charisma and his willingness to be ridiculous...But the real joy of the movie is when he does start to fight, and when it slowly dawns on everyone that he's an absolute alien fighting genius.

The plot which results in Lee's character being the salvation for a small Chinese restaurant under pressure from protectionist blackmail of a

1 Here, Lee makes reference to the Mahayana Lankavatara Sutra (Translated by D.T. Suzuki (2009)) which states "As the ignorant grasp the finger-tip and not the moon, so those who cling to the letter, know not my truth" (p. 193). This idea has been taken up by many Zen scholars as a parable emphasising the limitations of language and patterns of thinking to describe and thereby replace the spontaneity of immediate experience. Which evidently was Lee's lesson to his student on this day and a common message he imported into his teaching of the martial arts. It further highlights how his eclecticism was not limited to martial arts technique, but also philosophy too.

2 The notion of voiceless voice is also a deliberate connection with both Taoist and Zen logics where essences are sought lie within paradoxes and are intellectuality impossible to capture - such as the Tao De Ching's verse 41 "Loud is its sound, but never word it said." Lee uses this logic significantly in his work, for example describing his style as the "style of no style" which is also present in the Tao De Ching as the idea of the "Form of the Formless" (verse 14). 


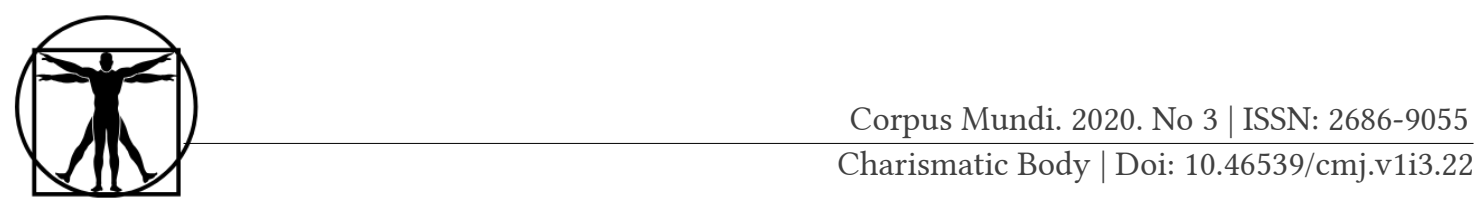

local mafia gang, comes face to face in a show down against a hitman martial artist (played by Chuck Norris) who the gang have bought in to silence Lee. They meet in the Italian Roman colosseum setting which is not just superficially iconic, but chosen to symbolise the place where the oppressed fought for their freedom from their oppressors. However, the freedom being fought for goes beyond the plot of the film, as with all of Lee's films, there is a story of salvation, cultivation and a transformative martial arts.

As the fighters warm up Lee strips to the waist (before Lee's films this practice was unheard of in Asian martial arts cinema) revealing a remarkably developed fighting torso, that literally embodies Lee's own maxim "absorb what is useful, discard what is not, add what is uniquely your own." Lee's adversary follows suit to reveal a fit but less strategically refined torso. The fighters begin, Lee's adversary is bigger, and both initially use traditional Karate and Kung Fu styles respectively. The adversary, as the larger man, quickly overpowers and drops Lee with a flurry of attacking karate punches and kicks whose traditional Kung Fu style is not proving effective against a bigger opponent with a powerful technique. The camera zooms in to show Lee dragging himself off the floor reflecting on what's to be done. Lee restarts and moves into Jeet Kune Do mode, shifting guards to a looser kickboxing stance with a dropped long range guard, dancing lightly around his opponent, he lunges with footwork borrowed from fencing, performs low kicks from Wing Chun, jabs and crosses from boxing, and combines these with Taekwondo and Shaolin style turning kicks, boxing parries and even Wing Chun low leg blocks.

At this point, the action goes into slow motion emphasising the unique transcultural combination of techniques, their execution, and Lee's physical conditioning in action. Lee's adversary is caught repeatedly with Lee's unpredictable attacks and visibly slows down until he himself is dropped. However, he is resilient, gets up and keeps coming forwards attacking and defending with the only style he knows, even though these tools and tactics are no longer working, portraying him as trapped by his own embodied martial tradition. Uniquely, the camera angle shifts to portray the adversary's blurred and wobbly perception as he stares bewildered at Lee, unable to innovate. The camera pans to a nearby kitten who is playing with a piece of paper like a cat with an injured mouse symbolising Lee's dominant ongoing strategy. Eventually, after declining the chance to submit the adversary is beaten and dies. Lee lays the fallen man's gi over his head and torso in an act of final respect and departs the scene to fight the rest of the gang. The scene carries the negative sym- 
bolism of being fixed in routine and tradition and, being oppressed and ultimately defeated by it; the adversary that cannot adapt.

By contrast, the salvational discourse is portrayed as Lee uses his body as a location and a means to show the martial art of Jeet Kune Do's "style of no style" as a solution to the problem of tradition in the martial arts through the cinematic genre (and in order to do this he had to reinvent the action movie genre too). Lee's art was presented as a concept offering the ability to adapt to the circumstances and not be bound by martial tradition. The symbolism is of course not limited to the martial arts but life in general. The scene and his performance in it, is a key legacy in the emergence of Lee's broader embodied charismatic affectif.

\section{POSTHUMOUS CHARISMATIC AFFECTIF: EMBODIED CHARISMATIC AFFECT IS NOT READILY TRANSFERRABLE AND DIES WITH BODY OF ITS BEARER - OR DOES IT?}

The key to immortality is first living a life worth remembering (C) Bruce Lee

The period for which Lee has become widely known for both his martial arts and his films was remarkably short and intense, spanning less than ten years (1964-1973). During this time however, Lee had conceptualised a new martial art, built a martial arts school with loyal followers, published a book on the subject (and partially wrote another), acted in and directed four films (and was working on a fifth), acted in a TV show of 26 episodes and made a number of other TV appearances. Moreover, this occurred in an international context with him increasingly moving backwards and forwards between the USA and Hong Kong. Lee's sudden death on July 20th, 1973, aged thirty-two caused a void that was not filled and is a particularly poignant illustration of Weber's point that (embodied) charisma is not readily transferrable and dies with body of its bearer. Parkin (1982, p. 86) captures Weber's point in the following:

Because charisma is a gift that inheres in the extraordinary, once-in-a-lifetime individual, it cannot be preserved and passed on. After the death of a charismatic figure there is a crisis of succession that can never be properly resolved. With the appointment of a successor things are never quite the same. Charisma is thus a flame that burns with a bright intensity for a short while and is then suddenly extinguished. In the aftermath of charismatic rule, authority reverts to a more traditional mould or starts to take on bureaucratic features. 


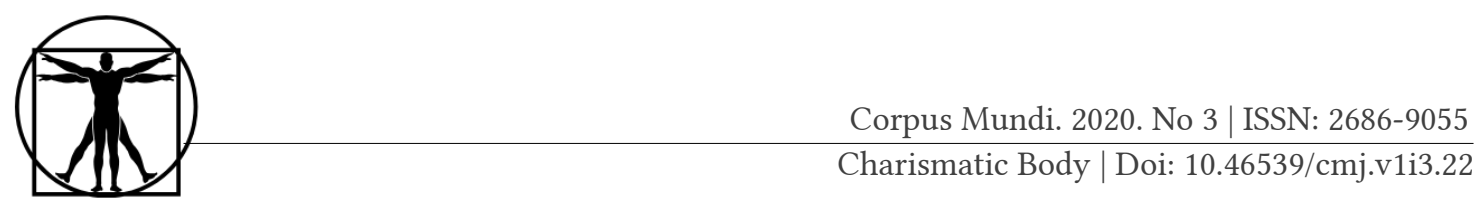

As Brown and Jennings (2011) point out, many established traditional martial practices are examples of living, performing art forms deliberatively passed down through the bodies of generations of practitioners with the most prominent example being the longstanding lineage of the Kung Fu monks of the Shaolin Temple. In these cultures, succession is a continuous concern, it is acutely understood that when a master martial artist dies, so does the precise "psycho-sensorium" of the art unless it has been appropriately "passed on" from the body of the master to the body of the chosen successor.

Bruce Lee had only conferred teacher status on three of his students, Taky Kimura, James Yimm Lee and Dan Inosanto. Each of these men had trained extensively with Bruce since he began his teaching in America from around 1964 and each of these men Bruce considered had grasped the essence of the practical and philosophical principles of Jun Fan Gung $\mathrm{Fu} /$ Jeet Kune Do. Since that point, Dan Inosanto has certified only relatively few instructors in Jeet Kune Do. In this way, a body-experience lineage (Brown \& Jennings, 2011) was created and along with it, an almost inevitable and slightly ironic process of simultaneous traditionalisation and bureaucratisation of Lee's art and his posthumous charismatic leadership. Even though none of these men were ever elected as successors, they nevertheless highlight a very significant part of Lee's charismatic affectif. Their bodies become living testimonies of a close physical connection with Bruce Lee (body-as-source), the skills and dispositions embedded within their bodies are seen as legitimate (body-as-location) and they use their bodies as a conduit to pass on the art and some of Lee's inspiration to others (body-as-means). It is generally agreed that these followers and teachers have continued to pass on Jeet Kune Do in the spirit in which Lee had taught them, as illustrated by Kimura (in Little, 1998, p. 17):

\footnotetext{
Even now my blood becomes feverish when I reflect upon those bygone days when Bruce and I were together...When Bruce was alive, he always pushed me in a direction that I believe he would wish all of us to follow: To fulfil to the utmost your physical capabilities which enable you to identify who you really are with humility and pride. Once this is accomplished, the door will open and you will enter the kingdom of philosophical spirituality.
}

Lee's embodied charismatic affectif continues to produce affects in others and via the bodies of others and artefacts that amplify and sustain Lee's embodied charisma. What is taking place here is a form of social synaesthesia as described by Freund (2009), grasped from close social and physical interaction with Lee's moving body and which served to "color, 
sharpen, change the tone and texture of experience" of this interpretation of martial arts, thus altering these practitioner's "psycho-sensorium - the embodied subjectivity through which we exist in the world." (Freund, 2009, p. 3) This connects with Mellor and Shilling's (1997) notion of "a 'recovered sensuousness' which reflects a developing consecration of the profane world" (1997, p. 161-2), and results in the reformulation of what they term sensual solidarities around the sensorial legacy emerging from affective intersubjective inter-corporeal interaction between Lee's body and the bodies of his students and their students. As Mellor and Shilling (1997, p. 174) reflect, "it is more usual for sensual solidarities to emerge from the immanence of the fleshy body with situations of co-presence and interdependence."

However, close charismatic relationships are only part Lee's embodied charismatic affect(if). Drawing on Shamir's (1995) notion, of distant charismatic leadership, along with Junker's (2014) idea of follower agency, it is possible to gain some insight into how Lee's embodied charismatic affect stretched beyond the confines of localised back and front stage performances (Joosse, 2012) and emerged as an affectif that reached a mediatised global audience, something he never lived to see to fruition. The mysterious death of Bruce Lee in 1973, a few weeks after the Hong Kong release of Enter the Dragon, which quickly attracted critical acclaim, created a cultural event that rippled across the world in martial art cultures and beyond. There was a sudden surge of interest in Lee's martial art and many other martial arts besides. The absence of certified Jeet Kune Do teachers led to many others beginning to teach Lee's art often claiming some embodied connection (having trained with Lee or one of his students, or indeed one of their students). Evidently, not all of these were deemed to be particularly, or even remotely close to Lee or his students in terms of lineage, ability or philosophy. The body of these teachers was deemed by his closest followers to be neither a source nor location through which Lee's charisma and teachings were sufficiently present.

Lee's mediatised life and death coincided with the rise of the viewer society or synopticon (Mathieson, 1977) where the many watch the few, and this context also contributed to Bruce Lee's affectif. Lee's embodied charismatic performances became increasingly mediated and remained a culturally anarchic affective force, reaching out across social space and time to attract followers, some of whom were not even born when Lee died. These posthumous followers were affected, inspired and empowered to act by the charisma conveyed through their mediated consumption of Lee's films, books, folklore and other edited footage of his performances. Wanting to be like Lee, but in their own way, under the influence of his 
ideas and practices, these distant followers engaged in mimesis and reinvention (Elliot, 2013) that was to sweep away many of the traditional meanings and practices in the martial arts as well as inspire a range of creative practices in the form of fitness training, nutritional, experimental film making techniques, and feelings of ethnic pride and empowerment.

However, relatively recently there has been something of a revival of an attempt to coordinate and guide the teaching of Lee's own martial art and re-direct the charismatic affectif that continues to drive demand for it in ways which are again suggestive of Elliot's (2013) notion of reinvention, with the underpinning principle of a sensual solidarity around the more specific psycho-sensorium advocated by Lee. Once again, the body is being used as a source, location and means to form a lineage of bodily and interpersonal sensorial contact with Lee himself. This situation is a prima facie case of Sennett's (1977, p. 274) commentary on the posthumous processes of a charismatic leader:

When a charismatic leader is destroyed, Weber argues, the phenomenon of charisma itself does not disappear. It becomes "routinized," by which he means that the office or position the charismatic leader held acquires an echo of excitement which once attached to his person. It is only at this point of transfer from the fallen man [sic] to the office that the charisma could be thought of as a stabilizing force; the office arouses some feeling because people have the memory of the great man [sic] who once filled it, and so the office acquires a certain legitimacy. But this "afterlife" of charisma is only a faint echo of the passion which surrounded the leader, and at the time when the leader is alive, the force of charisma is disruptive and anarchic.

The Bruce Lee Foundation, was established in 2002 as a registered charity (California 501(c)(3) public benefit corporation), that "seeks to preserve, perpetuate, and disseminate Bruce Lee's life example, philosophies, and art of Jun Fan Jeet Kune Do®" (www.bruceleefoundation.com). In coming into existence, this Foundation illustrates how the relationship between the charismatic body of Lee and the bodies of his closest followers came to be used as a means to continue his martial arts legacy. Following Joose's (2017) revitalisation of Weber's ideas, it is possible to see this development as one of the formal instantiation of charismatic aristocracy, which is is the explicit promotion of an inner circle or group of "-exemplary charismatic followers-followers who are exquisitely qualified to perform roles as valiantly subservient partners in the charismatic interaction" (Joose, 2017, p. 338). The BLF's board is an assemblage of lineage through experientially based training (including the three designated in- 
structors) and is run by Linda Cadwell, Lee's widow and Lee's daughter Shannon. Moreover, it is explicit in this regard stating:

The Bruce Lee Foundation, founded in 2002, is the only officially sanctioned charitable organization dedicated to Bruce Lee in the world and is the only public charity that is supported by Shannon Lee and Linda Lee Cadwell together with a number of Bruce Lee's original students and friends. The Bruce Lee Foundation presents the whole legacy of Bruce Lee to the world, portraying him not only as the martial artist and action star that he was but as the philosopher, friend, teacher, humanitarian, and family man as well.

The BLF is explicitly uncommitted to naming specific instructors of Fun Fan feet Kune Do, however what is illustrative is the BLF's conception that Lee's body still acts as a source, location and means for charisma and it survives through the (re)construction of body experience lineages. The BLF state:

Does your instructor have a direct lineage to a first generation instructor of JKD? In other words, did he [sic] ever study for a good length of time with one or more original students of Bruce Lee or one of the direct second generation students? This is important because this is one way to be sure that the instructor you are studying with has some basis for his knowledge other than books and movies.

Lee's embodied charismatic affect is thus carried by a charismatic aristocracy, something which implicitly narrows the legitimacy of possible instructors to a relatively small number of former inner circle followers. The basis for this authenticity is taken to be the quality and duration of embodied experience that person has had, either directly with Lee's charismatic body or by proxy with a close student of Lee's from the era. Following its interface with an emerging bureaucracy, Lee's embodied charismatic affect is, as Wetherell (2015) put it "affectively distributed" and becomes affectif. The BLF promotes the idea of Lee as emergent in the experiential communion of bodies who co-produce the martial art, producing a source of bio-agency transmitted and re-invented amongst adherents.

Bruce Lee's embodied charismatic affect continues to proliferate and produce affectif many years beyond his death in ways which move beyond transmission via human bodies and many of these going beyond the BLF's intentions. These now include an array of artefacts and technologies (Ash, 2015) ranging from a sacralised martial art, computer game characters, mimes, icons and effigies. First, and perhaps most poignant, Lee's 


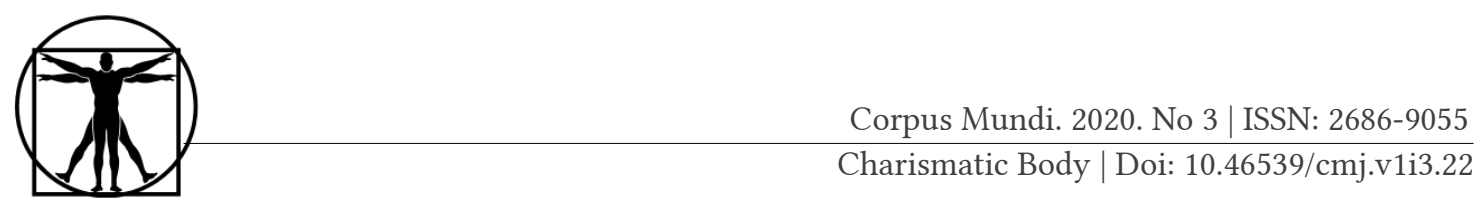

headstone in the Seattle cemetery where his body rests, is fittingly adorned with the words, "may your inspiration guide us toward our personal liberation." There is a significant pilgrimage of fans visiting this site to capture his charismatic affect, posthumously enlivened by those words. Statues are also particularly potent "affecting objects" (Ahmed, 2008) through which Bruce Lee's embodied charismatic affectif is distributed and sustained. For example, in 2005 a $7 \mathrm{ft}$ statue of Lee was unveiled in the Avenue of Stars, Hong Kong, to celebrate the 65th birthday anniversary of Lee with $\$ 100,000$ raised by the Rubão Fan Club. Also, in 2005 in Mostar, Bosnia and Herzegovina a statue of Bruce Lee was erected to provide a symbol of ethnic solidarity in a divided city ${ }^{1}$. In 2013, a $7 \mathrm{ft}$ bronze statue of Lee was erected in Los Angeles' China town's central plaza. Also, in Lee's father's ancestral town of Jun'an, Foshan in Guangdong province China, the local authority spent 158 million yuan building the "Bruce Lee Paradise Park" with the centre piece being an 18.8 metre bronze statue of Lee erected in memorial of the martial artist, a cultural claim to his ancestry and a clear bid to boost tourism through the allure of his enduring embodied charismatic celebrity.

Lee's distant embodied charismatic affect continues to draw on his body as source, location and means, in its mediated synoptical form, creating an affectif which inspires and empowers many followers across space and time affecting their own lives and self-reflexive identity projects.

\section{CONCLUSIONS}

Smith (2000, p. 105) reflects that the "utility of a theory can be seen in its ability to illuminate data" and Turner (2003, p. 5), despite his reservations about the concept of charisma contends that "no concept that is such a precise depiction of a continually recurring social phenomenon will go out of currency." This article has consulted a range of theory to argue that while widely used, charisma has not yet fully benefited from being revisited in light of work on the body and affect in social theory. Shilling's (2005) three modalities of how the body might be considered in relation to society: body as source, location and means for/of society, were drawn on to help focus the analysis on how charisma might be studied as an embodied phenomenon. These embodied dimensions were added to Weber's sociological interpretation of charisma (that charisma must be performed constantly, recognised by others, is not readily transferred and dies with the body of its bearer) to explore the role of the

1 It is worth noting this was a contentious event and not everyone subscribed the underlying symbolism provided by a statue of Lee. 
moving body of one charismatic leader exemplified through the case of Bruce Lee, and how his embodied charismatic affect emerged as "a driving creative force" (Giddens, 1971, p. 161) or affect(if) that stimulated social change.

The idea of embodied charismatic affect and affectif developed here leads to a number of more general observations. Firstly, returning to Shils (1965, p. 200-201), the secular and sacred aspects of charisma operate not as a dichotomy but rather on a continuum in which the unifying aspect is what he refers to as awe-arousing centrality, which is "some very central feature of man's [sic] existence and the cosmos in which he lives. The centrality coupled with intensity, makes it extraordinary." Moreover, what these awe-arousing centralities are taken to be are culturally and historically particular, arbitrary and unfixed. Drawing on the work of Sennett (1977) and Thrift (2010) it is suggested that figures like Bruce Lee illuminate the role that extraordinary embodied features and abilities play in constructing an intensity that provides the charismatic celebrity personality, with an allure of style which has become a powerful and often mysterious secularised social force. Second, that which becomes sacralised and charismatic or, for that matter, de-sacralised and uncharismatic might emerge from the bio-agency of (un)remarkable individuals colliding with particular historical and cultural time-space circumstances. Charismatics do not so much create a new awe-arousing centrality, rather they tend to exemplify or even reinvent one in response to a calling from potential followers. In this sense, charisma, like affect, does not "belong" to them, even though their bodies might be said to be sources, locations and means for the emergence of charismatic affect and affectif. Third, the above view shifts the locus of embodied charisma away from notions of the individual possession of a unique essence of person and towards the recognition that embodied charisma is rather an emergent form of bio-agency exercised via the body in movement, in specific spatial and temporal cultural contexts. Such a view concords with Varela's $(2009$, p. 321) notion of recovered agency, in which he concludes:

The essence of human existence is freedom: voluntarism is personal agency...personal agency is an emergent case of agent causality - selfmovement in nature...the agency (potentials: possibilities) of the person (agent: thing: substance) is the (causal) power(s) of action.

However, while we may be free to act, bio-agency, by its very nature, affects and is affected by matter beyond the individual. Lee's example highlights both how the moving body is centrally implicated as a "zone of emergence" in producing embodied charismatic affect. An affect that 
transmutes into affectif through its contagious, alluring, interpellating, dividual and fractal energy. Therefore, the essence of an embodied charismatic is the extraordinary, intense and successful exercising of agency through movement in a social field in which struggles around what Bourdieu (1993, p. 122) refers to as the legitimate body and legitimate uses of the body are emphatically presented. The highly charismatic individual successfully exercises bio-agency to affect her or his followers in ways that consecrate the profane, secular and even banal practices into things that can be inspirational sources of belief. Fourth, further examinations of connections between embodied charisma as a successful bio-agency and collectivist embodied sociological ideas including Freund's (2000) social synaesthesia, Mellor and Shillings (1997) sensual solidarities and Durkheim's (1915) collective effervescence are needed to implicate and better articulate the role of the aggregated social body in charismatic transmission and consecration of awe-arousing centralities.

Finally, the charismatic's body also plays an important role in constructing and maintaining what Shamir (1995) refers to as close and distant charismatic leadership. However, in agreement with Junker (2014), that close and distant followership also needs exploring at the same time, with particular attention to whether inspiration always leads to compliance or whether it can also inspire individual and collective agency through forms of empowerment in ways which supersede or deviate from the initial charismatic relationship. This all relates to the emergence of what Seyfert (2012) refers to as (charismatic) affectif. Of and on its own the view presented here is that there is no so such thing as a charismatic body and the socio-historical context in which a particular moving body is located is pivotal to its being considered charismatic. For embodied affect (which to a greater or lesser extent we all possess through our movement) to be seen as charismatic, other elements need to be in place. The various material and mediated ways in which Bruce Lee's localised affect became an affectif across time and space does reinforce Massumi's (2001, p. 9) point that movement, sensation and affect and the affectif that emerge from this is an ontogenetic process:

One of the things that the dimension of emergence is ontogenetically "prior to" is thus the very distinction between the individual and the collective, as well as any given model of their interaction. That interaction is precisely what takes form. That is what is socially determined and renegotiated by each and every cultural act.

In conclusion, charismatics are neither born nor made, but rather emerge as their individual bodies' move in historically and socially specific 
contexts of interaction with other people and objects. Charismatic's bodies are not charismatic in and of themselves, rather their moving bodies are involved in an ontogenetic process that creates a zone of emergence for charismatic affect to materialise.

\section{References}

Aberbach, D. (1996). Charisma in Politics, Religion and the Media: Private Trauma and Public Ideals. Hampshire: Palgrave Macmillan.

Adair-Toteff, C. (2005). Max Weber's charisma. Journal of Classical Sociology, 5(2), 189204. Doi: $10.1177 / 1468795 X 05053491$

Adair-Toteff, C. (2014). Max Weber's charismatic prophets. History of the Human Sciences, 27(1), 3-20. Doi: 10.11772F0 952695113518212

Ahmed, S. (2008). Imaginary prohibitions: Some preliminary remarks on the founding gestures of the new materialisms. European fournal of Women's Studies, 15(1), 23-39. Doi: 10.1177/1 $468795 X 05053491$

Ash, J. (2015). Emotion, space and society, technology and affect: Towards a theory of inorganically organised objects. Emotion, Space and Society, 14, 84-90. Doi: 10.1016/j.emospa.2013.12.017

Brown, D. H. K., Jennings, G., \& Leledaki, A. (2008). The changing charismatic status of the performing male body in Asian martial arts films. Sport in Society, 11(2-3), 174-194. Doi: 10.1080/17430430701823414

Brown, D. H. K. \& Leledaki, A. (2010). Eastern Movement Forms as Body-Self Transforming Cultural Practices in the West: Towards a Sociological Perspective. Cultural Sociology, 4(1), 123-154. Doi: 10.1177/1 749975509356866

Brown, D. H. K. (2011). La concezione weberiana del carisma: 1 caso delle arti marziali. Religioni e società (71), 42-60.

Brown, D. \& Jennings, G. (2011). Body lineage: conceptualizing the transmission of traditional Asian martial arts (in the West). STAPS: Revue Internationale des Sciences du Sport et de l'Education Physique, 32(93, 3), 61-71.

Brown, D. \& Jennings, G. (2013). In search of a martial habitus: Identifying core dispositions in Wing Chun and Taijiquan. In R.S. García and D. Spencer (Eds.) Fighting Scholars: Habitus and Ethnographies of Martial Arts and Combat Sports (pp. 33-48). London and New York: Anthem.

Basu, P. \& Werbner, H. (1999). Embodying Charisma: Modernity, Locality and the Performance of Emotion in Sufi Cults. London: Routledge.

Bauman, Z. (2000). Liquid Modernity. Cambridge: Polity Press.

Beck, U., Giddens, A. \& Lash, S. (1994). Reflexive Modernization: Politics, Traditions and Aesthetics of Modern Social Order. Cambridge: Polity Press.

Berger, P. (1967). The Sacred Canopy: Elements of a Sociological Theory of Religion. New York: Anchor Books.

Beyer, J. M. (1999). Taming and promoting charisma to change organizations. The Leadership Quarterly, 10(2), 307-330. Doi: 10.1016/S1048-9843(99)00 019-3 


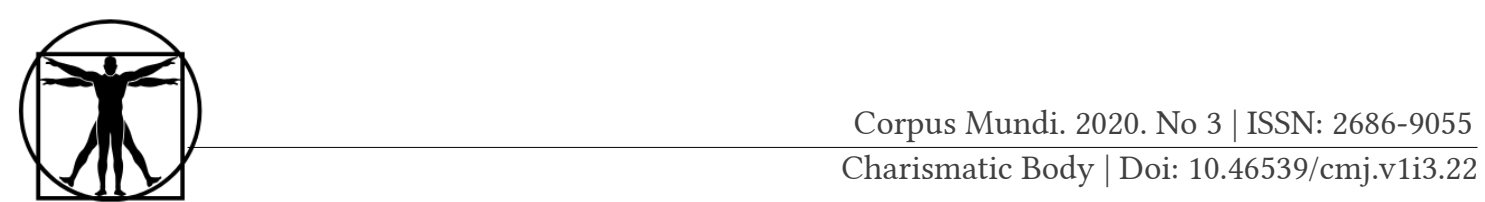

Beyer J. M. \& Browning, L. (1999) Transforming an industry in crisis: charisma, routinization, and supportive cultural leadership. The Leadership Quarterly, 10(3), 483-520. Doi: 10.1016/S1048-9843(99)00 026-0

Blackman, L. (2012). Immaterial Bodies. Affect, Embodiment, Mediation. London: Sage.

Bourdieu, P. (1993). Sociology in Question. London: Sage Publications.

Breihan, T. (2015). The Way of the Dragon Is a stone-cold classic for that one fight alone. The Concourse. Retrieved from: https://theconcourse.deadspin.com/theway-of-the-dragon-is-a-stone-cold-classic-for-that-1 695164125

Bruce Lee Foundation (2019) Retrieved from https://bruceleefoundation.org

Campbell, C. (2007). The Easternization of the West. London: Paradigm.

Csordas, T. J. (1997). Language, Charisma and Creativity. Berkeley, CA: University of California Press.

Durkheim, É. ([1915] 2001). The Elementary Forms of the Religious Life. Oxford: OUP.

Early, G. (1996). Baseball, boxing and the charisma of sport and race. In G. Early, E. Solomon, \& L. Wacquant (Eds.) The Charisma of Sport and Race (pp 1-46). Berkeley: University of California.

Elliot, A. (2013). Reinvention. London: Routledge.

Erez, A., Misangyi, V.F., Johnson, D.E., LuPine, M.M. \& Halverson, K.C. (2008). Stirring the hearts of followers: Charismatic leadership as the transferal of affect. Fournal of Applied Psychology, 93(3), 602-615. Doi: 10.1037/0021-9010.93.3.602

Feuerbach, L. ([1854] 2014) The Essence of Christianity. New York: Prometheus Books

Freund, P. (2009). Social synaesthesia: Expressive bodies, embodied charisma. Body \& Society, 15(4):21-31. Doi: 10.1177/1357 034X09347 220

Gardner, W. L., \& Avolio, B. J. (1998). The Charismatic relationship: A dramaturgical perspective. Academy of Management Review, 23(1), 32-58. Doi: 10.5465/ amr.1998.192958

Giddens, A. (1971). Capitalism and modern social theory: An analysis of the writings of Marx, Durkheim and Max Weber. Cambridge: Cambridge University Press.

Gramsci, A. (1971). Selections from the Prison Notebooks. London: Lawrence \& Wishart.

Harvey, D. (1992). The Condition of Postmodernity: An Enquiry into the Origins of Cultural Change. Oxford: Wiley-Blackwell.

Howell, J. M (1988). Two faces of charisma: Socialized and personalized leadership in organizations. In J. A. Conger, \& R. N. Kanungo (Eds.) Charismatic Leadership: The Elusive Factor In Organizational Effectiveness (pp. 213-236). San Francisco: Jossey-Bass.

Junker A. (2014). Follower agency and charismatic mobilization in Falun Gong. Sociology of Religion, 75(3), 418-441. Doi: 10.1093/socrel/sru021

Joosse P. (2012). The presentation of the charismatic self in everyday life: Reflections on a Canadian new religious movement. Sociology of Religion, 73(2), 174-199. Doi: $10.1093 /$ socrel/srr045

Joosse, P. (2014). Becoming a God: Max Weber and the social construction of charisma. Journal of Classical Sociology, 14(3), 266-283. Doi: 1468 795X14 536652 
Joosse, P. (2017). Max Weber's Disciples: Theorizing the charismatic aristocracy. Sociological Theory, 35(4), 334-358. Doi: 10.1177/0 735275117740402

Locke, S. (2004). Charisma and the iron cage: Rationalization, science and scientology. Social Compass, 51(1), 111-131. Doi: 10.11772F0 037768604040794

Lee, B. (1975). The Tao of feet Kune Do. California: Ohara Publications.

Lee-Cadwell, L. (1989). The Bruce Lee Story. Ohara publications: Santa Clarita, California.

Lewis, I. M. (1996). Religion in Context: Cults and Charisma. 2nd ed. Cambridge: Cambridge University Press.

Little, J. (1998). The Art of Expressing the Human Body. Boston: Tuttle Publishing.

Mathiesen, T. (1997). The viewer society: Michel Foucault's 'Panopticon' revisited. Theoretical Criminology, 1(2), 215-234. Doi: 10.11772F1362 480697001002003

Massumi, B. (2002). Parables for the Virtual: Movement, Affect, Sensation. London: Duke University Press.

Mellor, P., \& Shilling, C. (1997). Re-forming the Body: Religion, Community and Modernity. London: Sage.

Mullan, M. L. (1995). Sport As institutionalized charisma. Journal of Sport and Social Issues, 19(3), 285-306. Doi: 10.11772F0 19372395019003005

Parkin, F. (1982). Max Weber. London: Tavistock Publications.

Polly, M. (2018). Bruce Lee: A Life. London: Simon \& Schuster.

Rossen, J. (2015). Bruce Lee: The time Bruce Lee was challenged to a real fight. Mental Floss, 10th August . Retrieved fron http://mentalfloss.com/article/67 108/timebruce-lee-was-challenged-real-fight

Russo, C. (2016). Striking Distance: Bruce Lee and the Dawn of Martial Arts in America. Nebraska: University of Nebraska Press.

Scott, D. (2008). China and the International System, 1840-1949: Power, Presence, and Perceptions in a Century of Humiliation. State University of New York Press.

Sennett, R. ([1977] 2002). The Fall of Public Man. London: Penguin.

Seven, R. (1998). Gone but not forgotten -- Along his highway to fame, Bruce Lee changed a humble Seattle grocer's life. Seattle Times, Sunday, July 12. Retrieved from http://community.seattletimes.nwsource.com/archive/? date $=19980712 \&$ slug $=2760597$

Seyfert, R. (2012). Beyond personal feelings and collective emotions: towards a theory of social affect. Theory, Culture \& Society, 29(6), 27-46. Doi: 10.1177/0263276412438591

Shamir, B. (1995). Social distance and charisma: Theoretical notes and an exploratory study. The Leadership Quarterly, 6(1), 19-47. Doi: 10.1108/S1479357120180000009021

Shilling, C. (2013). The Body and Social Theory. (Third Edition). London: Sage.

Shilling, C. (2005). The Body in Culture, Technology And Society. London: Sage.

Shils, E. (1965). Charisma, order, and status. American Sociological Review. 30(2), 199213. Retrieved from https://www.jstor.org/stable/2 091564 


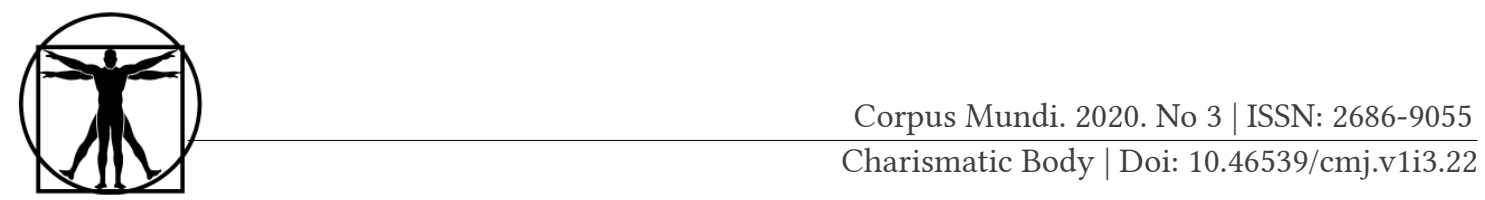

Smith, P. (2000). Culture and charisma: Outline of a theory. Acta Sociologica, 43, 101111. Doi: 10.1177/0 00169930004300201

Suzuki, D. T. (2009). The Lankavatara Sutra: A Mahayana Text (Tr. For the first time from the original Sanskrit). Motilal Banarsidass.

Storm, R. K. (2010). Professional team sports and profits-An irreconcilable combination? Systems theoretical observations on the sports business. In U. Wagner, R. K Storm, \& J. Hoberman (Eds.) Observing Sport: Modern System Theoretical Approaches (pp. 103-130). Schorndorf: Hofmann-Verlag.

Thomas, B. (1996). Bruce Lee: Fighting Spirit. London: Pan Books.

Thrift, N. (2000). Still life in nearly present time: The object of nature. Body \& Society, 6(3-4), 34-57. Doi: 10.1177/1357 034X00 006003003

Thrift, N. (2008). Non-Representational Theory: Space, Politics and Affect. London: Routledge.

Thrift, N. (2010). Understanding the material practices of glamour. In G. Mamssa, \& G. J. Seigworth (Eds.) The Affect Theory Reader (pp. 289-308). Durham: Duke University Press.

Tiryakian, E. A. (1995). Collective effervescence, social change and charisma: Durkheim, Weber and 1989. International Sociology, 10(3), 269-281. Doi: 10.1177/026858095010003002

Turner, B. (2003). Warrior charisma and the spiritualization of violence. Body \& Society, 9(4), 93-108. Doi: 10.1177/1357034 03773684676

Turner, S. (2003). Charisma reconsidered. fournal of Classical Sociology, 3(1), 5-26. Doi: 10.1177/1468 795X03003001692

Tzu, L. ([1891] 2006) The Tao Te Ching (Translated by James Legge). Gloucester: Dodo Press.

Varela, C. R. (2009). Science for Humanism. Oxon: Routledge.

Varga, I. (2005). The body - the new sacred? The body in hypermodernity. Current Sociology, 53(2), 209-235. Doi: 10.1177/0 011392105049538

Wallis, R. (1982). The social construction of charisma. Social Compass, 29, 25-39. Doi: 10.1177/0037 76868202900102

Webb, S. (2009). How Brice Lee Changed the World. A\&E Home Video.

Weber M. \& Eisenstadt, S. N. (1968). Max Weber on Charisma and Institution Building. Chicago: University of Chicago Press.

Weber M. ([1920] 1965). The Sociology of Religion. London: Methuen.

Wetherell, M. (2015). Trends in the turn to affect: A social psychological critique. Body \& Society, 21(2), 139-166. Doi: 10.1177/1357 034X14 539020

\section{Список литературы}

Aberbach, D. (1996). Charisma in Politics, Religion and the Media: Private Trauma and Public Ideals. Hampshire: Palgrave Macmillan.

Adair-Toteff, C. (2005). Max Weber's charisma. Journal of Classical Sociology, 5(2), 189204. Doi: $10.1177 / 1468795 X 05053491$ 
Adair-Toteff, C. (2014). Max Weber's charismatic prophets. History of the Human Sciences, 27(1), 3-20. Doi: 10.11772F0 952695113518212

Ahmed, S. (2008). Imaginary prohibitions: Some preliminary remarks on the founding gestures of the new materialisms. European fournal of Women's Studies, 15(1), 23-39. Doi: 10.1177/1468 795X05 053491

Ash, J. (2015). Emotion, space and society, technology and affect: Towards a theory of inorganically organised objects. Emotion, Space and Society, 14, 84-90. Doi: 10.1016/j.emospa.2013.12.017

Brown, D. H. K., Jennings, G., \& Leledaki, A. (2008). The changing charismatic status of the performing male body in Asian martial arts films. Sport in Society, 11(2-3), 174-194. Doi: 10.1080/17430430701823414

Brown, D. H. K. \& Leledaki, A. (2010). Eastern Movement Forms as Body-Self Transforming Cultural Practices in the West: Towards a Sociological Perspective. Cultural Sociology, 4(1), 123-154. Doi: 10.1177/1 749975509356866

Brown, D. H. K. (2011). La concezione weberiana del carisma: 1 caso delle arti marziali. Religioni e società (71), 42-60.

Brown, D. \& Jennings, G. (2011). Body lineage: conceptualizing the transmission of traditional Asian martial arts (in the West). STAPS: Revue Internationale des Sciences du Sport et de l'Education Physique, 32(93, 3), 61-71.

Brown, D. \& Jennings, G. (2013). In search of a martial habitus: Identifying core dispositions in Wing Chun and Taijiquan. In R.S. García and D. Spencer (Eds.) Fighting Scholars: Habitus and Ethnographies of Martial Arts and Combat Sports (pp. 33-48). London and New York: Anthem.

Basu, P. \& Werbner, H. (1999). Embodying Charisma: Modernity, Locality and the Performance of Emotion in Sufi Cults. London: Routledge.

Bauman, Z. (2000). Liquid Modernity. Cambridge: Polity Press.

Beck, U., Giddens, A. \& Lash, S. (1994). Reflexive Modernization: Politics, Traditions and Aesthetics of Modern Social Order. Cambridge: Polity Press.

Berger, P. (1967). The Sacred Canopy: Elements of a Sociological Theory of Religion. New York: Anchor Books.

Beyer, J. M. (1999). Taming and promoting charisma to change organizations. The Leadership Quarterly, 10(2), 307-330. Doi: 10.1016/S1048-9843(99)00 019-3

Beyer J. M. \& Browning, L. (1999) Transforming an industry in crisis: charisma, routinization, and supportive cultural leadership. The Leadership Quarterly, 10(3), 483-520. Doi: 10.1016/S1048-9843(99)00 026-0

Blackman, L. (2012). Immaterial Bodies. Affect, Embodiment, Mediation. London: Sage.

Bourdieu, P. (1993). Sociology in Question. London: Sage Publications.

Breihan, T. (2015). The Way of the Dragon Is a stone-cold classic for that one fight alone. The Concourse. Retrieved from: https://theconcourse.deadspin.com/theway-of-the-dragon-is-a-stone-cold-classic-for-that-1 695164125

Bruce Lee Foundation (2019) Retrieved from https://bruceleefoundation.org

Campbell, C. (2007). The Easternization of the West. London: Paradigm. 


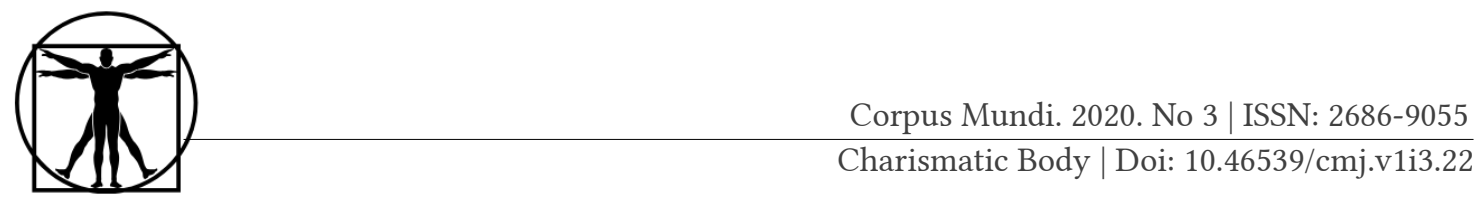

Csordas, T. J. (1997). Language, Charisma and Creativity. Berkeley, CA: University of California Press.

Durkheim, É. ([1915] 2001). The Elementary Forms of the Religious Life. Oxford: OUP.

Early, G. (1996). Baseball, boxing and the charisma of sport and race. In G. Early, E. Solomon, \& L. Wacquant (Eds.) The Charisma of Sport and Race (pp 1-46). Berkeley: University of California.

Elliot, A. (2013). Reinvention. London: Routledge.

Erez, A., Misangyi, V.F., Johnson, D.E., LuPine, M.M. \& Halverson, K.C. (2008). Stirring the hearts of followers: Charismatic leadership as the transferal of affect. Fournal of Applied Psychology, 93(3), 602-615. Doi: 10.1037/0021-9010.93.3.602

Feuerbach, L. ([1854] 2014) The Essence of Christianity. New York: Prometheus Books

Freund, P. (2009). Social synaesthesia: Expressive bodies, embodied charisma. Body \& Society, 15(4):21-31. Doi: 10.1177/1357 034X09347 220

Gardner, W. L., \& Avolio, B. J. (1998). The Charismatic relationship: A dramaturgical perspective. Academy of Management Review, 23(1), 32-58. Doi: 10.5465/ amr.1998.192958

Giddens, A. (1971). Capitalism and modern social theory: An analysis of the writings of Marx, Durkheim and Max Weber. Cambridge: Cambridge University Press.

Gramsci, A. (1971). Selections from the Prison Notebooks. London: Lawrence \& Wishart.

Harvey, D. (1992). The Condition of Postmodernity: An Enquiry into the Origins of Cultural Change. Oxford: Wiley-Blackwell.

Howell, J. M (1988). Two faces of charisma: Socialized and personalized leadership in organizations. In J. A. Conger, \& R. N. Kanungo (Eds.) Charismatic Leadership: The Elusive Factor In Organizational Effectiveness (pp. 213-236). San Francisco: Jossey-Bass.

Junker A. (2014). Follower agency and charismatic mobilization in Falun Gong. Sociology of Religion, 75(3), 418-441. Doi: 10.1093/socrel/sru021

Joosse P. (2012). The presentation of the charismatic self in everyday life: Reflections on a Canadian new religious movement. Sociology of Religion, 73(2), 174-199. Doi: $10.1093 /$ socrel/srr045

Joosse, P. (2014). Becoming a God: Max Weber and the social construction of charisma. fournal of Classical Sociology, 14(3), 266-283. Doi: 1468 795X14536 652

Joosse, P. (2017). Max Weber's Disciples: Theorizing the charismatic aristocracy. Sociological Theory, 35(4), 334-358. Doi: 10.1177/0 735275117740402

Locke, S. (2004). Charisma and the iron cage: Rationalization, science and scientology. Social Compass, 51(1), 111-131. Doi: 10.11772F0 037768604040794

Lee, B. (1975). The Tao of Jeet Kune Do. California: Ohara Publications.

Lee-Cadwell, L. (1989). The Bruce Lee Story. Ohara publications: Santa Clarita, California.

Lewis, I. M. (1996). Religion in Context: Cults and Charisma. 2nd ed. Cambridge: Cambridge University Press.

Little, J. (1998). The Art of Expressing the Human Body. Boston: Tuttle Publishing. 
Mathiesen, T. (1997). The viewer society: Michel Foucault's `Panopticon' revisited. Theoretical Criminology, 1(2), 215-234. Doi: 10.11772F1362 480697001002003

Massumi, B. (2002). Parables for the Virtual: Movement, Affect, Sensation. London: Duke University Press.

Mellor, P., \& Shilling, C. (1997). Re-forming the Body: Religion, Community and Modernity. London: Sage.

Mullan, M. L. (1995). Sport As institutionalized charisma. Fournal of Sport and Social Issues, 19(3), 285-306. Doi: 10.11772F0 19372395019003005

Parkin, F. (1982). Max Weber. London: Tavistock Publications.

Polly, M. (2018). Bruce Lee: A Life. London: Simon \& Schuster.

Rossen, J. (2015). Bruce Lee: The time Bruce Lee was challenged to a real fight. Mental Floss, 10th August . Retrieved fron http://mentalfloss.com/article/67 108/timebruce-lee-was-challenged-real-fight

Russo, C. (2016). Striking Distance: Bruce Lee and the Dawn of Martial Arts in America. Nebraska: University of Nebraska Press.

Scott, D. (2008). China and the International System, 1840-1949: Power, Presence, and Perceptions in a Century of Humiliation. State University of New York Press.

Sennett, R. ([1977] 2002). The Fall of Public Man. London: Penguin.

Seven, R. (1998). Gone but not forgotten -- Along his highway to fame, Bruce Lee changed a humble Seattle grocer's life. Seattle Times, Sunday, July 12. Retrieved from http://community.seattletimes.nwsource.com/archive/? date $=19980712 \&$ slug $=2760597$

Seyfert, R. (2012). Beyond personal feelings and collective emotions: towards a theory of social affect. Theory, Culture \& Society, 29(6), 27-46. Doi: 10.1177/0263276412438591

Shamir, B. (1995). Social distance and charisma: Theoretical notes and an exploratory study. The Leadership Quarterly, 6(1), 19-47. Doi: 10.1108/S1479357120180000009021

Shilling, C. (2013). The Body and Social Theory. (Third Edition). London: Sage.

Shilling, C. (2005). The Body in Culture, Technology And Society. London: Sage.

Shils, E. (1965). Charisma, order, and status. American Sociological Review. 30(2), 199213. Retrieved from https://www.jstor.org/stable/2 091564

Smith, P. (2000). Culture and charisma: Outline of a theory. Acta Sociologica, 43, 101111. Doi: 10.1177/0 00169930004300201

Suzuki, D. T. (2009). The Lankavatara Sutra: A Mahayana Text (Tr. For the first time from the original Sanskrit). Motilal Banarsidass.

Storm, R. K. (2010). Professional team sports and profits-An irreconcilable combination? Systems theoretical observations on the sports business. In U. Wagner, R. K Storm, \& J. Hoberman (Eds.) Observing Sport: Modern System Theoretical Approaches (pp. 103-130). Schorndorf: Hofmann-Verlag.

Thomas, B. (1996). Bruce Lee: Fighting Spirit. London: Pan Books.

Thrift, N. (2000). Still life in nearly present time: The object of nature. Body \& Society, 6(3-4), 34-57. Doi: 10.1177/1357 034X00 006003003 


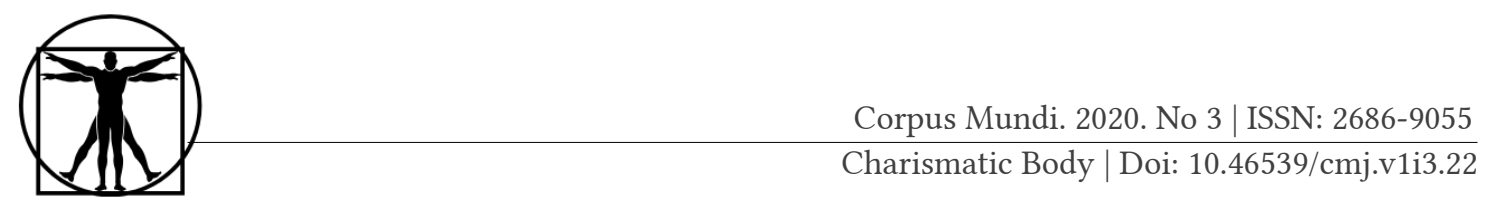

Thrift, N. (2008). Non-Representational Theory: Space, Politics and Affect. London: Routledge.

Thrift, N. (2010). Understanding the material practices of glamour. In G. Mamssa, \& G. J. Seigworth (Eds.) The Affect Theory Reader (pp. 289-308). Durham: Duke University Press.

Tiryakian, E. A. (1995). Collective effervescence, social change and charisma: Durkheim, Weber and 1989. International Sociology, 10(3), 269-281. Doi: 10.1177/026858095010003002

Turner, B. (2003). Warrior charisma and the spiritualization of violence. Body \& Society, 9(4), 93-108. Doi: 10.1177/1357034037 73684676

Turner, S. (2003). Charisma reconsidered. Fournal of Classical Sociology, 3(1), 5-26. Doi: 10.1177/1468 795X03 003001692

Tzu, L. ([1891] 2006) The Tao Te Ching (Translated by James Legge). Gloucester: Dodo Press.

Varela, C. R. (2009). Science for Humanism. Oxon: Routledge.

Varga, I. (2005). The body - the new sacred? The body in hypermodernity. Current Sociology, 53(2), 209-235. Doi: 10.1177/0 011392105049538

Wallis, R. (1982). The social construction of charisma. Social Compass, 29, 25-39. Doi: 10.1177/0 03776868202900102

Webb, S. (2009). How Brice Lee Changed the World. A\&E Home Video.

Weber M. \& Eisenstadt, S. N. (1968). Max Weber on Charisma and Institution Building. Chicago: University of Chicago Press.

Weber M. ([1920] 1965). The Sociology of Religion. London: Methuen.

Wetherell, M. (2015). Trends in the turn to affect: A social psychological critique. Body \& Society, 21(2), 139-166. Doi: 10.1177/1357 034X14 539020 